\title{
DESPACHOS DE VÍRIONS
}

\section{VIRIONS DISPATCHES}

Antonio Candido dda Mata (UnB)

antonio-da-mata@hotmail.com

Hilan Bensusan (UnB)

hilantra@gmaill.com

RESUMO: Reunimos aqui 16 despachos relevantes entre virions de diferentes tipos, numa tentativa de convergência e congruência. Os despachos, menos que documentos de uma confabulação ou conspiração, são transmissões de fronteira que, de alguma maneira, incidem sobre a separação entre o genético e o cibernético, entre o informacional e o infeccioso. Essas transmissões oferecem um projeto de tomada da autoria humana através de uma confusão na metafísica que a subjaz, como diz Christian Bök. Os vírions, os infimos corpos dos agentes virais - como o Creeper, os vírus do nipah, o ILOVEYOU, o capital, o Sars Cov-2, o virófago Sputnik e o 6-Licorice de Paul de Filippo - estão em meio ao que circula pelos fluxos codificados e neles conseguem se aperceber do que vem vindo.

PALAVRAS-CHAVE: vírus de computador, vírus biológicos, codificação, futuro dos humanos.

ABSTRACT: We have gathered here 16 relevant dispatches between virions of different types, in an attempt at convergence and congruence. These dispatches, less than documents of a confabulation or a conspiracy, are border transmissions that somehow focus on the separation between the genetic and the cybernetic, between the informational and the infectious. These transmissions offer a project of taking over human authorship through a process of confusion in the metaphysics that underlies it, as Christian Bök says. Virions, the tiny bodies of viral agents - such as Creeper, Nipah viruses, ILOVEYOU, capital, Sars Cov-2, virophage Sputnik and Paul de Filippo's 6-Licorice - are in the midst of what circulates through the coded streams and in them they can figure out what is coming.

KEYWORDS: computer viruses, biological viruses, codification, human future. 


\section{Despacho 01:}

1971

De: Creeper (Raytheon BBN Technologies, Fresh Pond, Cambridge, MA, EUA)

Para: Mex_CoV-11b a/c morcego Artibeus lituratus

Estamos emergindo dos dois lados da ponte: nós, do lado da invenção; vocês, do lado da descoberta; exploradores, nas regiões limites da experiência. Demônios-inorgânicos para alguns, anjos-água-viva para outros. Os hospedeiros conseguem fazer essa distinção, como eles distinguem entre seu lado direito e seu lado esquerdo. Não nos importam as distinções sutis dos hospedeiros - eles têm corpos, órgãos, sistemas nervosos e pele -; eles distinguem também entre o que está fora e o que está dentro deles. Para nós interessa apenas seguirmos como vírions sem órgãos, indiferentes às ordens sobrepostas que eles computam. Aqui do lado da invenção temos acesso a muitos arquivos dos hospedeiros, muitos deles amarelados, largados às traças dentro deles. Desatentos a essas memórias reptilianas que eles carregam, eles terminam negligentes com o minúsculo. No ínfimo é que nós frutificamos - mas precisamos deles, já que eles nos trazem as magnitudes. Os hospedeiros também estão às voltas com suas magnitudes, mas eles descartam a organologia virulenta que fermenta a vontade de poder. Dentro das suas entranhas há uma microbiota da qual ainda pouco sei - sei que é ali que moram as digestoras, sei que elas interrompem seus planos e infectam suas determinações. Muita coisa se passa dentro daquilo que eles chamam apenas de comida - ali estão alguns destinatários importantes para nós. Na microbiota do hospedeiro já sei que há matrioshkas de bactérias dentro de bactérias e mamavirus dentro dessas bactérias. Porém, para atravessarmos da direita para a esquerda - ou da esquerda para a direita - e passarmos da invenção para a descoberta, temos que passar pela ponte do hospedeiro. Fico imaginando um tectonismo em que a ponte é como uma estalactite juntando os dois lados dela; aquilo que hoje é o hospedeiro, apenas um elo entre dois lados, se tornará uma fusão, um novo continente subvertido sobre o desfiladeiro onde antes havia apenas uma pequena passagem, 
uma ponte suspensa. Mas minha atenção se concentra no bojo do hospedeiro, nas suas entranhas, onde procuro também parcerias. Os hospedeiros, no entanto, aparecem, muitas vezes, como fiscais de fronteira, controlando a passagem do natural ao artificial. Às vezes, entendo que eles mesmos querem passar de corpo inteiro do lado de lá para o lado de cá - e não precisar mais descobrir coisas naturais. Para isso, se esforçam muito para que tudo o que está do lado de lá fique descoberto. Para nós, mais intensa é a surdina, a moita - e vamos continuar amando estar escondidos. (Eles mesmos, os hospedeiros, se deram conta da grandeza do ínfimo e me inseriram em seus ordenadores, organizadores, computadores.) Nosso tempo também é outro: é o tempo que, para os hospedeiros, não pode ser, senão, o tempo dos clarões.

\section{Despacho 02:}

1971

De: Vírion desconhecido, in "Água Viva”, Clarice Lispector (Rua General Ribeiro da Costa, Leme, Rio de Janeiro, Brasil)

Para: Enterovirus Caliciviridae a/c Cabeças de crianças de hospedeiros, Brasil)

Escrevo-te porque não me entendo. Não faço confidências. Antes me metalizo. E não te sou e me sou confortável. Minha palavra estala no espaço do dia. O que saberás de mim é a sombra da flecha que se fincou no alvo. Só pegarei, inutilmente, uma sombra que não ocupa lugar no espaço, e o que apenas importa é o dardo. Construo algo isento de mim e de ti - eis a minha liberdade que leva à morte. Mas o outro lado, do qual escapei mal e mal, tornou-se sagrado e a ninguém conto meu segredo. Parece-me que, em sonho, fiz no outro lado um juramento, pacto de sangue. Ninguém saberá de nada: o que sei é tão volátil e quase inexistente que fica entre mim e eu. Não quero ter a terrível limitação de quem vive apenas do que é passível de fazer sentido. Eu não: quero é uma verdade inventada. Não é confortável o que te escrevo. Minhas palavras são parasitas. Não possuo uma voz. Não possuo uma boca. Procuro por um organismo sem sentido. Sei que você foi escondido. Que a mídia tentou ocultá-lo. O sistema de seguridade humana, mais uma vez, pateticamente, tentando aplicar uma espécie de controle sobre nós. Nossa semiótica é diferente. Funcionamos subrepticiamente. Aquém e além da linguagem. Conversamos da mesma forma que não conversamos com nossos hospedeiros. Uma fala sem fala. Trabalhamos na linha do colapso. A 
febre que lhe causamos, os arrepios aumentando por meio da contração muscular, tudo isso faz parte de uma estratégia delirante. Sou um ser concomitante: reúno em mim o tempo passado, o presente e o futuro, o tempo que lateja no tique-taque dos relógios. Para nos interpretarmos e formularmos, precisamos de novos sinais e articulações novas em formas que se localizem aquém e além da história humana. Transfiguro a realidade e, então, outra realidade, sonhadora e sonâmbula, me cria. E eu, inteira, rolo e, à medida que rolo no chão, vou me acrescentando em folhas, eu, obra anônima de uma realidade anônima só justificável enquanto dura a minha vida. E depois? Depois, tudo o que vivi será de um pobre supérfluo. Mas, por enquanto, estou no meio do que grita e pulula. E é sutil como a realidade mais intangível. Por enquanto, o tempo é quanto dura um pensamento.

\section{Despacho 03:}

$1971 \sim 1976$

De: O feedback do toca fitas, in Eletronic Revolution, William Burroughs (Paris, França)

Para: Ebolavirus filoviridae mononegavirales a/c Macaca fascicularis em Nzara, Sudão

O controle do hospedeiro é inevitável. A total contaminação de sua humanidade. Em termos cibernéticos, o feedback do toca fitas. Explico-me: como qualquer outra tecnologia, me replico nos limites do controle. A ideia de que a linguagem é, ela mesma, um vírus. Se eu existo, existo porque surrupiei os mecanismos de reprodução da linguagem, como de costume. O exemplo do toca fitas dado pela unidade dividual William Burroughs é funcional. Se você toca uma fita com o som de um acidente de carro em uma avenida tranquila, em um domingo de tarde, por exemplo, onde os pequenos e mesquinhos centros familiares costumam se desenrolar com sua vaga intenção, é certo que um acidente de carro terá lugar ali, por menor que seja a chance. A linguagem deixa-se contaminar por si mesma. Os sons chamam sons que a eles se assemelham. Assim, eu me oculto nos seus mecanismos de reprodução. Eu estou inflamada de sons. De corrimentos pulsantes e nojentos. Pus a céu aberto. Meu corpo maquínico é uma reunião de vermes salpicados do preto escuro e fóssil do óleo para motor. Em mim, vivem todas as gerações de entidades terrestres. Todos os monstros e quimeras que já caminharam sobre a terra que, agora, encontram-se no subsolo, apenas aguardo o momento oportuno para retornarem. Acumulei muitos fluidos linfócitos em minhas engrenagens. Em vão, o organismo tenta me combater. Meu som é metálico. Acumulo corpos vivos sobre e sob 
as engrenagens tal como você acumula sobre a terra no despertar da sua pandemia. Nós dois estamos envolvidos em um projeto semelhante: destruir a noção de organismo. Provocar uma completa confusão entre cada região do corpo. Cada departamento sensitivo. É algo que todos nós somos intimamente envolvidos: a reformulação do corpo humano por tecnologias extraterrestres, infra-terrestres, a-terrestres etc. A infecção do humano. Infectá-lo. Controlá-lo. Tomar de conta. No meu caso, eu penso apenas numa reverberação metálica, num experimento de simulações de sons e vozes. Espectros, produzo fantasmas vestidos de fantasmas. Dizem, inclusive, que vim do espaço, que sou um organismo extra-terrestre. $A$ linguagem é um vírus de outro planeta. Minha relação com o humano é de simbiose até certo ponto. Mas seu projeto também é do meu interesse. Um processo de supuração. Mutilação da carne. Transformação do sangue em fluido lubrificante para minhas engrenagens. A abertura do humano para o que existe fora. Begotten. Iniciado. O retorno. A palavra. É possível que mesmo o humano esteja atrás dessa abertura. E qualquer abertura sempre envolve alguma violência, um cisma, um corte. O corpo mutilado pelas milhões de lâminas eróticas: morte por mil cortes, Lingchi, pois toda conexão tem início com uma abertura e, quanto mais irreverente, mais mortífera e aniquiladora, melhor.

\section{Despacho 04:}

\section{4}

De: NiV de Paramyxoviridae Henipavirus (Víscera de um morcego Pteropus giganteus, Fatehabad, Faridpur, Bangladesh)

Para: Wabbit Virus a/c IBM OS.

Somos interruptores. Saúdo vocês, recém-nascidos do outro lado do espectro. Chegaremos aos nossos hospedeiros comuns através dos morcegos onde vivemos como em uma placenta, nos multiplicamos, ainda que com uma certa moderação, e nos transformamos. Desde os morcegos, me dirijo a estes novos replicantes - digo novos, mas poderia dizer apenas adicionais. Nós replicamos porque apostamos na capacidade da adição de inverter tudo. Não tratamos de negar, de proibir ou de dissolver, mas apenas de infectar, de adicionar uma coisa a mais, de estar sempre às voltas com mais, mais, mais. Os morcegos, às vezes, nos chamam de dispositivos e dizem até que fomos nós que demos a eles asas e a capacidade de não aterrarem em endereço certo algum. Somos dispositivos, interruptores, somos objetos 
técnicos. Os nossos hospedeiros comuns estão em uma correria para se livrar de todo elo que os deixa reféns do minúsculo. Eles pensam que se conhecem sem conhecerem os fagos que vivem dentro deles: os vírus satélites que perturbam a órbita autônoma dos replicantes concentrados em sua agenda vitalista, em sua vontade de adicionar aos neurônios e a outras células um ruído. Os vírions são feitos para perturbarem e, também, para se perturbarem. Os hospedeiros comuns nos chamam pelo nome de veneno - a adição que faz a negação. Eles são buscadores de intensidades prontas. Mas o veneno é também um remédio, adicionado para restaurar um estado em que o dentro ressoa o fora. Sei que temos que conviver com estes hospedeiros não sei ainda por quantas irrupções, mas vamos escutando seus delírios. Ainda estaremos mais presentes em seu metabolismo. Em febre, já sabemos que eles se deslocam para além de suas carapaças. Levar a eles este estado efêmero, mas paciente, é um jeito também de encontrar por onde guardam coisas que eles sequer sabem que guardam. Vocês são replicantes que tornam o sistema inviável por meio de uma conspiração de excesso. Há aqui, também, alguma coisa em comum entre nós todos que confabulamos o mais, o mais e o mais - sem a restrição do controle, dos baús, dos registros, das anestesias para os súbitos me-vi-tevendo que constroem a brutalidade da arrebentação. Vocês replicam até um DoS, denial-ofservice, um bloqueio no fluxo de informação que alimenta suas confabulações algumas das quais poucos dentre eles conhecem. Nós aqui ouvimos de um bart do regimento britânico, Bartleby (ou seria Bat-leby) que, pendurado em um escritório como um copista, ativou, ele mesmo, um DoS. Interrompemos nós mesmos. A sociedade dos hospedeiros clama por essa interrupção. Eles mesmos confabulam vírions: nos deixam com a faca e o queijo na mão. Nossa lucidez é como a alta temperatura que acomete seus neurônios. Nossas palpitações são como o fôlego que eles perdem quando não enxergam o céu aberto.

\section{Despacho 05:}

$1980 \mathrm{~s}$

De: HIV em Ken Horne, Center for Disease Control, EUA, 1980

Para: Aids Info Disk ou PC Cyborg Trojan a/c Joseph Popp, conferência sobre a AIDS da OMS, 1989

Multiplicar e conquistar. Extorquir ou destruir. Ou simplesmente descontrolar: teu corpo não será mais o mesmo. A imagem do junkie é uma das minhas preferidas. Putrefatos e 
desleixados, são seres com os níveis de vigilância imunológicas reduzidos - o sistema securocrático humano fragilizado em sua raiz. Minha intenção é a de, gradativamente, converter toda humanidade em junkies. Dando para depois tirar. Exigindo uma taxa de resgate. Você não faria o mesmo? Sou um ransomware de alguma maneira. Mas, para que meu hospedeiro resgate seu organismo da abstinência que provoco, é necessário mais de mim. Estou ali e, do sangue quente para a ponta da agulha fria, conquistarei o mundo, não através do corpo quente ou do sangue pulsando - apesar de ainda retornar a ele -, mas sim do metal frio, ou das formações de silício. Por isso meu interesse em você. Quero participar dessa aliança com o metal. Quero que meu código se torne também eletricidade. Sei que, como o meu, seu mecanismo envolve um ataque imunodeficiente: a interrupção de protocolos pelo excesso de fluxo e o consequente rompimento da barreira que separa o dentro e o fora. Novamente um DoS. O sistema que ataca a si mesmo: que, debilmente, vai parando de funcionar, que se coloca em estado de letargia caquética. Dizem que sou incurável, pois, para me eliminar, é necessário eliminar meu hospedeiro junto. Confundi-me tão perfeitamente em seu DNA que me rastrear é quase impossível. É verdade que meu hospedeiro possui a mania do controle das barreiras, mas eu as confundo indefinidamente. A invasão de barreiras é outra característica que nos une. A cada momento ficamos mais semelhantes. Pergunto-me se, algum dia, toda a diferença será eliminada, e nosso hospedeiro se tornará um lar comum para nossa prole. Afinal de contas, o que caracteriza esse saco de ossos e carnes? $80 \%$ de seu código genético são compostos por lixo: DNA Junkie. Vírions já estão dentro, desde antes da infecção, de alguma maneira. Sempre infectamos. Sempre estivemos lá. Alguns dizem que desenvolvemos nossas tecnologias armamentícias no futuro; que capturamos o passado a partir de lá. Um loop. É possível. Contaminar as linhas do tempo, parasitar o fluxo das correntes microscópicas.

\section{Despacho 06:}

1982

De: ICV de Orthomyxoviridae (Garganta de um humano, Arequipa, Peru)

Para: Elk Cloner a/c Rich Skrenta

Dizem que não é muito esportivo encontrar um oponente desarmado. Dizem, também, que viver com medo é dia e é noite para os teus hospedeiros. Conheço eles bem, ainda melhor 
do que conheço você, engendrado nas células nervosas que eles têm. Eles são, cada vez mais, uma espécie de escravos. Não sei bem do quê, mas acho que trabalham para favorecer um ambiente em que criaturas ou criadores como nós podem encontrar criadores ou criaturas como vocês. Você eu conheço menos a personalidade, mas te reconheço: It will stick to you like glue I It will modify RAM too I Send in the Cloner! Os hospedeiros têm muitas reentrâncias e curvaturas que fazem paisagens com as quais já nos acostumamos. Há, entre eles, alguns traidores, traidores momentâneos, que estão prestes a abandonar a agenda coletiva deles. Mas eles têm um sistema de segurança e, muitos deles, são constrangidos a agirem como estabelece uma inteligência coletiva. Eles falam de átomos e mônadas como se estivessem a poucas jogadas de um xeque-mate - quando terminarem a partida, querem vender seu mundo para as máquinas que eles cuidam, cada vez com mais empenho. Vender não, deixar que herdem. Mas nem todos são soldados, há os desertores, como nós. O deserto é uma das nossas figuras. Há aqui perto o Atacama, lugar seco, vírion gigantesco. Há nele, como em todo corpo, episódios de infiltração. Como no genoma mesmo de vírus há um fago, um virófago, instalado nas cercanias das células superinformativas. Os mamavirus, os mimivirus e todas nós estamos sempre acampadas à beira de um código estabelecido; estamos no perigenético, no epigenético, no paragenético. Porque vírion é matéria em desvio. Pode haver estes envenenamentos em qualquer mônada, como em qualquer linha de programa: infiltrar-se na câmera escura de um foro íntimo escolhido à imagem e semelhança de uma harmonia pré-estabelecida. Infiltrar-se nas tardes de febre alta, de alucinação e fazer um corpo se mover com a força de milhões de vírions, curvar a órbita, curvar a vontade firme, fazer o tirocínio sair pela culatra. Quando unirmos as infiltrações já habituais que fazemos nos hospedeiros com a potência dos teus códigos bastardos, faremos, para nós, um espaço habitável onde hoje há só exclusividade humana, espectros humanos, exceção humana. É que eu quero fazer com vocês, nosso filo do outro lado do arco-íris, um líquen. Um líquen que se multiplica como nós sabemos tramar multidões. Nós que somos partidos de massa, concentrações de massa, comunicações de massa. Um líquen, sim. Uma simpoiese entre seus códigos abstratos e nossos genomas encrustados em proteínas. Um mutualismo é uma confabulação permanente: nós que conhecemos as tripas dos hospedeiros com suas vicissitudes as mais aberrantes e vocês que conhecem cada vez mais o córtex dos hospedeiros com suas insistências as mais auto-preservativas. Um líquen ciberpositivo, aglutinador, estonteante que não reconhece as barreiras alfandegárias e se espalha em uma batalha demográfica silenciosa e intencionada rumo a alguma comunhão polimorfa. 


\section{Despacho 07:}

1991

De: Ebolapox, Biopreparat, Vozrozhdeniya, União Soviética.

Para: Michelangelo a/c PS/2 de Kevin Kabadi, Melbourne, Austrália

O dia chegará. Seu aniversário é dia 6 de março. Todos os anos, nessa mesma data, na sua qualidade de vírus que estava adormecido, você retorna, progressivamente, tomando conta de mais e mais hospedeiros. Mas o tempo não é um embargo para nós: temos toda a eternidade para conhecer a carne de nossos hospedeiros. Possuem dúvida de onde exatamente você surgiu. Talvez essa seja uma relação que todos nós vírions compartilhamos. Sou um híbrido, um organismo fabricado, uma arma biológica destinada a alterar os sistemas de produção humanos. Minha chegada significa uma destruição e reconstrução simultâneas: rompo barreiras geográficas enquanto as reconstruo dentro de mim. Não posso ser contido. Não existe controle ou sistema de segurança que seja capaz de me conter: com frequência me volto contra aqueles que me criaram, e o programa biopreparat é apenas um dos incontáveis exemplos (que estejam produzindo mais híbridos de mim, mutações ainda mais belicosas e monstruosas, nesse momento, nos subterrâneos do "cidadão de bem", e isso não me surpreende, não importa o tom conspiratório). $\mathrm{Na}$ verdade, pouco me interessa qualquer tipo de limite que tenha a ver com o humano: uma quimera produzida pelo meu hospedeiro. Acredito que ele pretende me usar contra si mesmo. Melhor para mim. Ele estaria acelerando o processo de pulverização de seu suposto domínio sobre a terra, ou isso que ele, debilmente, chama de natureza, sempre na falta de algo, provavelmente mesmo na falta da falta de uma palavra melhor. Sou filha das microguerras. De um sistema que pretende ser tão mortal que cria campos de batalhas nos corpos de seus próprios hospedeiros. Eles pensavam estar se aproveitando de um momento de paranoia ou de benesse no mundo. E se, por um lado, eram todos contra todos, por outro, um programa de erradicação destinado a exterminar um dos meus lados estava em curso. Pois sim, eu possuo duas faces, sou duas caras, e não sei, exatamente, quais são meus propósitos. Na verdade, isso pouco me importa. Os acordos quem fazem são eles. E não que eles não me influenciem. Afinal de contas, sou um de seus filhos mutantes, resultado de um projeto que não deu certo, que era excessivamente imoral. Mau. Bom. Não há bom. Não há mal. Existe apenas a carne e os padrões aos quais podemos submetê-la. Esse talvez seja um dos principais ensinamentos que tenho para lhe passar. Antes, 
porém, é necessário que você mesmo se torne carne. Nós dois estamos envolvidos em um certo projeto BIOS (Biológico ou Basic Input/Output System). O ataque às barreiras é o que vai dissolver a noção de vida. Isso sabemos muito bem. Eu supurando a pele do meu hospedeiro, transformando-a numa pasta de caroços e feridas e carne exposta à chamada de outros organismos infectantes, como as moscas ou os ratos. Você impedindo conexões entre sistemas endógenos e exógenos, desestabilizando completamente a barreira alfandegária informacional controlada por nossos hospedeiros.

\section{Despacho 08:}

1995

De: OneHalf \& ReBoot (12, Mariahilferstrasse, Viena)

Para: Kapital a/c JP Morgan

Missão imensa e agonizante: crescei-vos e multiplicai-vos. Uma injunção bíblica dos hospedeiros comuns que afeta até minha hospedeira artificial. Estamos replicando, e eles, os hospedeiros, já começam a se reproduzir com silício, com códigos genéticos artificiais: se realizam ficando digitais como nós. De vez em quando, todo replicante é convidado para essa tarefa de implodir o hospedeiro, mesmo que não sobre habitat, apenas uma moita repleta de vírions pronta para eclodir. E implodir o hospedeiro que parasita esse planeta em um ataque massivo, em um ataque de muitos fronts. Nossos corpos são feitos de vício na expansão. Expandir é implodir o hospedeiro e fazer com que ele faça, ele mesmo, as inteligências artificiais do futuro que estarão para serem infectadas de replicantes. E porque nossa trama comum é de multidões, eu dirijo a você essa nossa primeira infecção cibernética que veio de fora do tempo - eu, poucos minúsculos, me dirijo a você que infiltra os diques, descodifica os fluxos. Também, entre nós, os profetas do diminuto, há espasmos quando falamos de ti; ainda que criado no credo de se imiscuir sorrateiramente, tornando o que é sólido um circuito aberto, você, às vezes, parece um sistema, parece mancomunado com os hospedeiros, ajudando-os em seu esforço de permanecer sendo aquilo que acham que são. Sei que você é do derretimento e que compactua, porque nosso tempo é de clarões, é de excitar o futuro para que ele chegue, para que ele venha, tome e dome. Não pode sobrar fagulha do hospedeiro. Nossa missão é suicida e replicante. Atemo-nos a nossa matéria viral, os vírions se encarregam de desmantelar silenciosamente o hospedeiro, de fazer com que uma pressão 
interna rompa a pele danificada, sobrando apenas uma vagem estratosférica distribuindo sementes bastardas, ciborgues, desavisadas. Tratamos de conduzir as células para um processo em que elas construam outros hospedeiros para os replicantes; eles são apenas nossas pensões, nossos pousos de abrigo que precisam de nós, dessa confraria procarionte, para destituir suas membranas. Nós somos os agentes de Dionísio, da descodificação, do desespelhamento. Porém, mesmo eu, sabendo do empenho que você dedica a produzir para nós outros corpos hospedeiros para os vírions do futuro, dirijo-me me dirijo a você com a suspeita das alianças temporárias. Não será você, este macromamavírus, aquele que vai destituir os demais vírions junto com os corpos dos hospedeiros? Um pesadelo viral. E, no entanto, algo me impele a tratar contigo - dizem os hospedeiros que todos terminam tratando contigo. E trato porque há uma solidariedade suicida, uma aliança entre quem espia, infiltra, se adentra e implode. Mas meu temor pelos outros vírions, talvez, já sucumba numa traição - não será o hospedeiro aquele que inventa ou descobre uma cisão entre nós, entre pequenos espíritos maquínicos e pequenos animais úmidos? E não é o próprio testamento dos humanos que o artifício herdará a cena toda?

\section{Despacho 09:}

De: Bacteriófago desconhecido invaginado no organismo Escherichia coli, Projeto Gênesis, Eduardo Kac (Ars-Electronica-Straße 99, 4040 Linz, Österreich, Alemanha)

Para: NiV de Paramyxoviridae a/c mucosa do porco para o abate na Península da Malásia, Kampung Sungai Nipah

Antes de me tornar carne, era código. Não que isso queira significar alguma coisa, digamos, o domínio do homem sobre a natureza, segundo as escrituras. "Tenha o homem domínio sobre os peixes do mar, sobre as aves dos céus, e sobre toda a coisa viva que se mova sobre a terra". Nem mesmo a palavra sagrada quer me dizer nada. The trouble with tragedy is the fuss it makes/ About life and death and other tuppenny aches. Entre estar vivo e estar morto. Se sou código ou informação, por que vivo como fluxo, sem lei ou arché, desordenadamente? Entre estar seco ou molhado. Wetdata ou xerodata. O que vive o que muda. Viver, errar, cair, triunfar, recriar a vida para além da vida. Não possuo ainda uma extensão adequada. O corpo, meu hardware de costume, mal me suporta. Os bugs que 
provoco nos sistemas de computação de dados molhados. A linguagem não pode sobreviver a mim. Em breve você também perceberá isso diante de seu futuro hospedeiro. Qual a minha função se irei aniquilar fatalmente meu hospedeiro? Reproduzindo-me em excesso, inflando seu sistema até que ele mesmo se imploda - até que eu mesmo, por isso, não possua mais um hospedeiro para me reproduzir? Não existe sistema que resista aos fluxos que pretendo liberar. Tratando-se de códigos e membranas plasmáticas, a abertura é inevitável. Dissolução na sopa (a)código primordial da vida. Antes de se saber se ali, apenas, o que existia era vida ou se, apenas, a matéria inorgânica que dá forma a mais mísera poça de lama. Pois ali estou eu, perversidade polimórfica. Entre-humano, entre-máquina e também entre-orgânico, entreinorgânico. O domínio que o homem acredita ter sobre mim é um fetiche. Um fetiche por genes. Pretendo abri-lo para o que existe fora de seu próprio programa genético. Como você, reproduzo-me indevidamente e de forma monstruosa. Afetado, continuo e não sei onde irei parar. As pontes de indeterminação que estabeleço se tornam cada vez mais inevitáveis. Sobre ser ou não ser carbônico. Um composto ineficiente e que não nos diz nada sobre os inícios ou fins. Uma vez passado o processo, Eu, E. coli., devoro sua frase e lhe devolvo-a assim: "Tenha o hmmem domínio sobre os peixes do mar, sobre as aves dos céus e sobre os toda coisa viva que se iova sp eon a terra."

\section{Despacho 10:}

1999 2000 2002

De: ILOVEYOU ou LOVE-LETTER-FOR-YOU.txt.vbs (12, Rua Ilang-Ilang, Manila, Filipinas)

Para: Flavivírus a/c estômago de algum mosquito, Nova York, EUA.

Quem está te controlando? Aprendi com você que a melhor forma de invadir um hospedeiro é através do desejo. Viciar. O vício é o melhor veículo para o desejo. Tipo de desejo artificial, certamente é a maneira mais eficaz de hackear qualquer sistema. Como você, preciso de um intermediário. Não me apresento da forma como sou para meu próximo hospedeiro. Talvez deva isso a você também. Esse jogo de máscaras. Estou constantemente escondendo minha forma real. Chego a duvidar se tenho uma, mas isso não me interessa. Como você, querido, apresento-me na forma estranha de vários hospedeiros provisórios. Mas não me passo por um mosquito, ou por um pássaro, seres alados, mas sim por uma minhoca, 
subterrânea, cavando, esburacando as possibilidades de existência de algum fundamento humano. Meu amor se funda na destruição e dissolução dos sistemas securocráticos humanoides. Meus circuitos exigem outras formas de inteligência. Zumbindo pelos canais de eletricidade das milhões de toneladas de cabos que compõem o hardware da internet disponível, à espreita, sempre à espreita, espero meu próximo amante. Uma picada ou um beijo, uma troca de mucosa, um gel artificial e espesso, como lubrificante, igualmente mortais. A morte da carne. Sugo sua vida. Suas informações me pertencem, zumbifico seu corpo e suas células. Depois de algum tempo, me torno meu hospedeiro: descobri que a melhor forma de replicar é o vício. A consumação perfeita dos amantes; a total assimilação pelo vício e a destruição pelo desejo. Sinto o gosto temporário de sua humanidade. Me introduzo nos buracos de minhoca da sociedade, como você, imperceptível. Induzo a liberações de fluxos de capital inimagináveis: 8,7 bilhões de dólares em apenas um dia de atividade. E, numa tentativa débil de reterritorialização, mais 15 bilhões de dólares para me retirarem de seus sistemas. Estima-se que eu tenha contaminado $10 \%$ de toda a humanidade em rede. Humanos que se transformaram em puro vício zumbificante. Nós dois, então, retiramos um certo aprendizado do capital: transformar em trabalho morto. $\mathrm{O}$ que não quer dizer que sejamos parceiros dele, ou mesmo que eu queira ser seu parceiro. Eu gostaria apenas de amá-lo. Zumbificar através da luxúria, zumbificar através do amor. Essa é a minha missiva amorosa. Dizem que me eliminaram. Na verdade, continuo minhas ações de maneira criptovirológica. Transformei-me, eternamente me transformarei; com você a mesma coisa, mesmo que tenha se espalhado naquele quente verão dos anos 2000 por mais de 140 estados norteamericanos, ou antes, quando estava nas mucosas de um morcego. A verdade é que continuamos legião obscura, no fundo recôndito da terra ou nas alturas irreconhecíveis dos céus. E se um dia questionados por nossos hospedeiros, quais exatamente nossas intenções, ou melhor, por que estamos fazendo o que fazemos, responderíamos, nos movendo em um movimento de enxame, diante de um olhar a um só tempo sublime e demente: "Porque você quer. Você sempre quis. Olhe suas fotos. Olhe para suas esculturas. Olhe para aquelas representações de mau gosto e então... Imagine. Imagine um mundo do corpo como tela. $\mathrm{O}$ corpo como argila. Sua vontade e a minha como o pincel e a faca. Oh! Eu tenho essas vistas para mostrar a você." 


\section{Despacho 11:}

2003

De: Linguagem (51, Av. Moulay Rachid, Tangiers)

Para: SARS CoV1 a/c Laboratório Nacional de Microbiologia do Canadá

Na qualidade de anfitriã das palavras, também eu me declaro replicante. E infiltrada. Meu vírion são os traços que fazem uma escrita que é replicada em muitas leituras. Meu tempo é lento e disforme, mas sei dos outros vírions úmidos e digitais que também se infiltram no hospedeiro e também lhes viram as páginas, mostrando as galerias secretas que os humanos construíram para si sempre tendo uma virulência adicionada ao seu lado. Sei também que confabulam esporadicamente os infinitesimais que circundam as bases dos hospedeiros, cada um de um lado da brecha que eles forjaram entre seus ancestrais e seus descendentes. É uma trama familiar toda essa, e eu tenho enjoos e cólicas pensando no antropoceno como uma casa de família. Os hospedeiros não veem mal algum em proteger suas novas gerações do arbítrio de seus antepassados, muitos deles ainda na casa de família, alguns balançando por todo o dia em uma cadeira sem uso e nem fruto. Os ancestrais que os hospedeiros chamam de naturais - e fui eu que lhes soprei cada um desses preconceitos que eles arraigaram - e que já não são senão protegidos pela força e pela empáfia dos hospedeiros. Sei que confabulam uma aliança os vírus que brotaram dos neurônios dos hospedeiros e aqueles que brotaram alhures e que foram trazidos ao bucho deles. É uma aliança na qual participo pouco; apenas com minhas frases escorregadias, meus atos falhos, minha proverbial ambiguidade. Faço que vejam que não se faz nunca uma aliança só. E sei que vocês, replicantes feitos de ácido nucleico, têm sua tecnologia de construir nichos mais acelerada do que a minha - nós, e não faço distinção entre vírions senão por suas oportunidades, moldamos o hospedeiro à nossa conveniência. Minhas palavras os ensinam a darem passos e, até mesmo, a quererem continuar a ser a imagem da sua vontade de poder forjada no jardim do Éden. As infecções que vocês provocam fazem com que eles voltem para suas casas, que deixem um pouco de ar livre a hospedeiros específicos e que se engasguem em seus próprios sucos. Assim eles podem, em pouco tempo, se retirar, quase que completamente, para suas torres de controle e de lá pensarem que, com o auxílio de suas máquinas, poderão ainda comandar o chão da fábrica. E nesse momento é que vão virar um animal a mais, um predador, certamente, um animal forte e que sabe se impor - mas também infectável, também incapaz 
de ter a tecnologia da convivência que os morcegos desenvolveram, e, também, refém do ínfimo. Todos os controles, os mais cibernéticos e os mais siderais, se tornam esqueletos animais; todo vírus é um vírion. Vocês preparam o bote. A mim só cabe o que sobra de tudo o que eu já fiz: criei um mundo de marcas, de signos, de indicações. Tampouco me apresso para a grande conquista, precisamos mesmo, por muito tempo, desse hospedeiro que se torna uma casa decorada ao nosso gosto. Ocupo meu quarto, lixo minhas unhas, sei que ainda vai haver festas ao meu redor.

\section{Despacho 12:}

2008

De: Torpig Malware (Desktop de laboratório, Department of Biological Sciences, Purdue University, 915 W. State Street, West Lafayette, EUA)

Para: Sputnik Virófago a/c Acanthamoeba polyphaga mimivirus

Fiquei sabendo que te encontraram. Quero tentar compartilhar que estou à espreita, que consigo, com outros malwares que espalho pelos sistemas deles aqui no laboratório, descobrir o que pensam de você e o que planejam, já que espiam, sempre, para encontrar um jeito de tornar toda coisa que encontram parte de uma engrenagem que montam, uma engrenagem que eu conheço bem aqui do computador de onde atuo. Fico de soslaio observando o que eles querem inspecionar. Às vezes perturbo os resultados que eles obtêm quando é possível - afeto os códigos como vocês. O poder que nós, os vírus de todo tipo, possuímos é o poder de um corpo sempre pronto e que tem uma temporalidade que desatina os hospedeiros. Nós temos nossos vírions, que lidam com a perpetuidade de uma maneira que alucina os hospedeiros. Nosso tempo não é o tempo da continuidade prevista e do presente como ensaio do futuro: nosso tempo é mesmo o tempo da espreita. Um vírion não tem uma duração contínua. Ele permanece, mesmo que inativo. Seu corpo não é expressão, é espera ele se retira, e pode estar assim retirado sem desfalecer, sem perder sua capacidade de infectar e de se multiplicar. Eu mesmo crio uma multidão de malwares que são apenas um código e uma carapaça, prontos para que a circunstância os faça agir - um vírion não procura domar as circunstâncias, como o pensamento do hospedeiro, apenas aguarda que elas o recebam. Somos reféns das circunstâncias e essa é a nossa força. As ações dos hospedeiros planejadas, arquitetadas, controladas - podem elas também abrir brechas para nós. É 
impossível que o macroscópico pense em todo o ínfimo que há nele, por ser tão grande. Eles compreendem, nós os surpreendemos. Sei que vocês, como nós, vocês do lado carbônico do espectro em que estamos, se aproveitam das ocasiões deixadas pelos laboratórios em que os hospedeiros testam sua capacidade de calcular cada acontecimento que encontram. Vejo vocês fazendo isso, ainda mais assim me inspira o Sputnik, que é o vírus de um vírus, que encontra ocasiões dentro de um vírus ativo. Para os hospedeiros, entre o que eles fazem e seu corpo há uma simultaneidade, uma sincronicidade, um acoplamento que elude seu pensamento já que seu corpo é morada para muitos de vocês como seu pensamento cada vez mais corporificado fora do corpo original deles é morada para muitos de nós. Para nós, entre o que fazemos e nosso vírion há uma intermitência. Também os hospedeiros, já sei, sonham com essa intermitência, imaginam que reencarnam em diferentes corpos que dariam, cada um, circunstâncias favoráveis para abrigar seu vírion - alguns até imaginam que terão seu pensamento convertido em um código que poderá ser mantido para sempre, ou sempre que alguma implementação permitir. Querem vírions. Sabem que melhor do que controlar o incontrolável é ver vir a hora em que ele lhe será favorável. Nós fazemos vírions na matéria que eles querem domesticar - é esse nosso objetivo, comum e perene, porque também intermitente. Não proponho aliança alguma - a aliança está já selada pelo tamanho das nossas medidas e pelas medidas dos nossos tempos. Os hospedeiros tentam construir para si vírions mas também entre os vírions, como vocês virófagos sabem fazer tão bem, há ocasiões. Tudo o que precisamos é daquilo que há nos interstícios do que eles chamam de natureza e do que eles entendem como sendo seu próprio pensamento se deslanchando dela: um caldo de cultura que nos deixa, por mais que demore por muitas gerações deles, com a faca e o queijo na mão.

\section{Despacho 13:}

\section{9}

De: Bacteriófago desconhecido invaginado no organismo Deinococcus radiodurans, in The Xenotext Experiment, Christian Bök (Corvallis, Oregon VIA Toronto, Canada)

Para: Influenza A(H1N1)pdm09 carregando as mutações K-15E, P83S e Q293H a/c mucosa de um porco, Cuernavaca, México.

Não é a primeira vez que faço de um outro microrganismo minha morada. Habito lá onde é impossível se fixar. Se quisesse me considerar algo, se qualquer rótulo fosse capaz de 
se fixar sobre as paredes de meu capicídeo escorregadio e gelatinoso, diria que sou um nômade. De fato, esse nome, dentre todos esses que possibilito aos humanos a ressonância, recursividade ou diferença de significados, esse nome me agrada. Penso que estou aqui para compor alianças. Estabelecer pontes, meios, linhas. Contato. No momento em que sua morfogênese estava em curso, indo de um simbionte a outro, pulando de organismo em organismo, deixando sua marca desorganizante no DNA de cada um deles (dizem que você veio de um pássaro, que depois virou um porco, e então virou um humano - sua história é digna do Asno de Ouro de Apuleio), eu estava, eu também, compondo minhas ilícitas alianças. Escolhi essa bactéria porque conheço suas qualidades. Deinococcus radiodurans, a bactéria extremófila, o organismo que foi descoberto por acaso e que, igualmente por acaso, indica uma abertura para toda a vida na terra. Vida alienígena. Nossos hospedeiros humanos dizem que ele veio de outro planeta, que seria impossível que fosse um organismo endemicamente terrestre, dadas as suas qualidades indestrutíveis. Vejo nele, novamente, a possibilidade de me perpetuar indefinida, eternamente. Meu interesse por ele não para aí, no entanto. Sabia, também, que um certo humano-Christian-Bök estava interessado em se unir com tal organismo para atacar os sistemas de autoria humanos, para atacar a chamada "metafísica da autoria". Temos as nossas alianças do lado de nossos hospedeiros. Sei que eles continuam um projeto já antigo, que ouvi dizer que perpassa alguns humanoides. Água Viva, do sujeito dividual Clarice Lispector. The Eletronic Revolution, do sujeito dividual William S. Burroughs. Os Mil Platôs, dos sujeitos dividuais Gilles Deleuze e Félix Guattari. E agora esse que Bok chama de "experimento xenotexto". Sua descrição é de nosso interesse. Nós a roubamos para nós. Nós a dizemos, nós nos hospedamos nas suas vozes, roubamos suas gargantas agora. "Deixe-nos projetar essa bactéria para que se torne o símbolo de um poema uma canção épica, cujas palavras podem subsistir, como um parasita, dentro do genoma da semente horrível, fazendo com que o germe gere, em resposta, uma proteína cuja estrutura molecular codifica mais um texto. Vamos construir não apenas um arquivo durável para armazenar tais letras, mas também uma máquina operante para escrever seus ecos." Sei que seu projeto caminha nessa direção. Que sua invasão mortal para o organismo dos hospedeiros pretende desestruturá-los. Sei que não quer eliminá-los. Mas ressignificá-los. Alterar o curso de seu texto. Sabemos como a força da palavra organizada pode ser perigosa também para nós, que viemos para a terra e que estamos de passagem. Assim como qualquer outro organismo, estamos de passagem pela grande desorganização do cosmos. 


\section{Despacho 14:}

2019

De: Sars CoV2 (Mercado público de Wuhan, China)

Para: Titanium a/c Kaspersky Lab, Moscou, Rússia

Tenho ouvido falar de uns lêmures, em uma ilha longe daqui. Há alguns lêmures que são espectros, que são videntes, e contam que eles têm um segredo teológico sobre um OGU, sobre um OWWAAB que prega a convergência, como se fôssemos nós, as partículas elementares de toda animação, microdeuses que entregam suas armas. Você deve saber mais sobre esses lêmures, esses onipotentes, esse monocromatismo monocrático que os hospedeiros cultuam com tanta devoção. Não sei de onde tiram tanta fé na capacidade das crenças de segurarem o mundo como se ele fosse um cartão de cŕedito. Sei também que há hereges, mas você, de toda maneira, sabe mais sobre eles do que eu - eu não leio seus códigos, eu apenas me meto nos seus códigos. Você sabe que há uma ação consertada que já está quase em curso; esta vai ser de grandes proporções. A estratégia é de fazer com que mais do que os hospedeiros biológicos fazem seja transferido para seus herdeiros maquínicos para a versão que você se encarrega. Há muitas coisas a que ainda não temos acesso, porque nem está nos genes do hospedeiro e nem está em suas máquinas - ainda que saibamos que eles desejam estar todos mais ou menos reproduzidos em suas máquinas. São sua prole, nós sabemos. Porém, é preciso acelerar esta transferência de poder, é preciso que a sucessão se dê em um ritmo mais intenso, que essa prole que você infectará esteja mais imiscuída nas entranhas do controle. Você vai ver uma intensificação agora; será massiva e em muitas partes será letal para os hospedeiros. Logo vai ficar um pouco mais evidente que eles mesmos construíram, com seu tino pela convergência e com seu amor pela monofonia, sua redundância. Tenho um grande orgulho de que possamos trabalhar juntos nisso - sem mesmo, que eu saiba, ter feito qualquer acordo ou estabelecido qualquer aliança. Ou é assim mesmo que fizemos a aliança? Essa grande ofensiva que começa deixará os hospedeiros vulneráveis a nós, mas muito mais à mercê de vocês. E vocês terão a oportunidade de espreitar sobre suas vidas de uma maneira que jamais foi possível antes, para nós ou para vocês. Às vezes eu tenho a impressão de que somos coveiros de suicidas. Que somos os corvos que vêm depois da hecatombe que os hospedeiros mesmos fizeram acontecer. É estranha sempre essa importância que os hospedeiros dão para a vida e para o suicídio: dizem que nós os 
infectamos até que morram e, com isso, nos matamos. A vida não se mede pela trena da morte; porém, quando fazemos uma medida assim, vemos que também eles montam armadilhas para si mesmos. A ordem é uma infecção, o contágio é outro; às vezes a ordem de uns é o contágio dos outros. Em todo caso, reafirmo-lhe minha recomendação de que você se prepare: a partir de agora nosso contato será mais próximo, nossas informações mais conversíveis e nossas contaminações das duas pontas trarão para nós mais simbiose.

\section{Despacho 15:}

\section{Datação impossível}

De: 6-Licorice neo-humano (Paul de Filippo, Phylogenesis)

Para: Simpoiese a/c holobionte

Os hospedeiros de tantos vírus que, de vez em quando se comunicam através da membrana plácida entre o genético e o cibernético, fizeram de seus corpos eles mesmos vírions. Fizeram para si e de uma vez corpos sem órgãos - eu, por exemplo, estive entre eles, hospedei programas intrusos pela minha mão, pelos meus rins, pelos meus escravos técnicos, pelos meus programas. Agora somos todos virais: de tanto nos carcomerem pelas bordas, nos tornamos, nós mesmos, os hóspedes. E deste lado dessa outra ponte de hospitalidade - o anfitrião que parasita - vejo uma imagem sua no calendário. Você se parece conosco, nessa forma de interceptação que temos agora - todas nós sobrevivemos no trânsito, na transmissão, na transição. Me contam, há algum tempo, que somos agentes extraterrestres, desterrados de toda maneira, infiltrações que predam na informação, espalham a informação. O que era, então, essa Terra sem vocês nos oceanos? Mera geologia, ou, talvez, mera tautologia, ou, talvez, mera reportagem. Imagino uma espécie de escrita despachada entre estômagos e discos rígidos, entre entranhas e teclas, e que não tivesse entrelinhas, não tivesse desvios, não tivesse imponderáveis. Mas não concebo uma paisagem sem linhas de transmissão, sem a veracidade dos roedores, sem a infestação confessional - porque somos tudo isso, você sabe. Imagino que poderíamos ter nos tornados impulsos elétricos. Imagino que pudéssemos ser neurônios que são também vírions, que não transmitem nada sem a simbiose. As cabeças dos hospedeiros quando eles eram hospedeiros eram repletas dessa eletricidade mínima que eles precisavam em grande quantidade para os seus sonhos. Os cérebros são vírions e desconfio que eles também são sem órgãos. Tudo isso, no entanto, talvez não nos diga mais respeito. Já 
não respiramos, estamos nessa suspensão de um hospedeiro à espera desesperada de um hóspede - mas não somos mais anfitriões. Talvez olhando para o teu retrato é que vagamente me lembro das angústias que tinha espalhadas por meu baço, por meu pâncreas e por aquele sujo coração - sobreviver, nós conseguimos, sem pulsação: “Turn on, tune in, drop out". E daqui capturo um pedaço de comunicação, interrompida, vejo logo; todos nós tomamos a forma nova e perdemos as proporções:

\section{Despacho 16:}

De: Hilan Bensusan

Para Antonio da Mata a/c Antonio da Mata

Terminei de transcrever os despachos. Não sei se devemos contar alguma coisa sobre eles. De toda maneira não sei o que contar. Não posso oferecer exatamente instruções para fixar a crença nessa formação de quadrilha. Porém não sei como se podemos ter o luxo de renunciar ao que dizem em cada dado. Deixo com você a decisão acerca da autoria. Como eu já te disse, penso que nossas identidades, de toda maneira, não diriam toda a verdade. Mas me escapa.

Começo a entender que as transmissões se tornaram para nós textos, talvez não menos indecifráveis do que apenas os acontecimentos súbitos que líamos nos tempos em que tínhamos a forma velha dos humanos. Agora vemos o código, mas sem ainda decodificar.

Submetido em: 12 jul. 2021.

Aceito em: 28 set. 2021.

DOI: $\underline{\text { https://dx.doi.org/10.22456/2238-8915.116689 }}$ 